\title{
Quantitative comparison of WHO tobacco control measures: lessons from the Eastern Mediterranean Region
}

Gholamreza Heydari ${ }^{1}$

${ }^{1}$ Tobacco Prevention and Control Research Center, National Research Institute of Tuberculosis and Lung Diseases, Shahid Beheshti University of Medical Sciences, Tehran, Islamic Republic of Iran (Correspondence to: G. Heydari: ghrheydari@yahoo.com)

\begin{abstract}
Background: In 2008, the World Health Organization (WHO) introduced a package of measures including 6 main policies (MPOWER) to control tobacco use.
\end{abstract}

Aims: This study aimed to perform a quantitative analysis of MPOWER in the WHO regions.

Methods: This cross-sectional study collected information in summer 2018 using pages 136-149 of the 2017 MPOWER report and a validated check list with 10 criteria, with a possible maximum score of 37 . The scores were summed and presented in descending order for the 6 WHO regions.

Results: The highest mean score was recorded by the European Region (26.41), followed by: South-East Asia Region (25), Western Pacific Region (24.88), Region of the Americas (22.05), Eastern Mediterranean Region (21.40) and African Region (17.40). There were significant differences $(P<0.05)$ in the means.

Conclusions: Although many efforts have been made in the Eastern Mediterranean Region, many challenges to policy implementation and enforcement remain compared with other regions, and require urgent action by governments in the Region.

Keywords: Eastern Mediterranean Region, MPOWER, policies, tobacco control, tobacco use

Citation: Gholamreza H. Quantitative comparison of global tobacco control policies: lessons from the Eastern Mediterranean Region. East Mediterr Health J. 2020;26(1):9-17. https://doi.org/10.26719/2020.26.1.9

Received: 05/01/19; accepted: 10/11/19

Copyright (c) World Health Organization (WHO) 2020. Open Access. Some rights reserved. This work is available under the CC BY-NC-SA 3.0 IGO license (https://creativecommons.org/licenses/by-nc-sa/3.o/igo).

\section{Introduction}

The hazards of smoking make the need for implementation of tobacco control programmes undeniable (1). Tobacco use remains the leading preventable cause of morbidity and mortality worldwide, and the rates of morbidity and mortality due to smoking-related diseases are rising. The prevalence of smoking has shifted from developed to developing countries during the last few decades and is increasing $(2,3)$. The first and the most important strategy to confront this situation is the comprehensive implementation of tobacco control programmes $(4,5)$. In this regard, the World Health Organization (WHO) negotiated the Framework Convention on Tobacco Control (FCTC) treaty in 2003, and so far, 181 countries have ratified it (6). In 2008, a package of measures was proposed for implementation, which included 6 main components: monitoring tobacco use and prevention policies; protection of people from tobacco smoke; offer of help to quit tobacco use; warning people about the dangers of tobacco; enforcing bans on tobacco advertising, promotion and sponsorship; and increasing taxes on tobacco (7). Global experiences have revealed that implementation of the above-mentioned strategies can effectively decrease the rate of consumption and consequences and complications of tobacco use (8-11). Some studies have shown that this type of analysis may pose a challenge to countries to improve their tobacco control status $(12,13)$. A study in 2015 revealed the 15 countries with the highest scores for tobacco control worldwide (14).

Lessons can be learned from 10 years of implementing WHO FCTC and the demonstrated benefit in combating tobacco use $(15,16)$. Cairney and Mamudu (17) reported that the best approach to tobacco control requires specific policy processes, namely: the department of health takes the policy lead; tobacco is framed as a public health problem; public health groups are consulted at the expense of tobacco control interests; socioeconomic conditions are conducive to policy change; and the scientific evidence is "set in stone" within governments. No country can meet all these requirements in a short period, and there is a wide gap between the expectations of implementing such programmes and the actual situation in many countries, particularly in the WHO Eastern Mediterranean Region. In 2016 and 2017, 2 studies showed that WHO FCTC implementation in the Region had not improved greatly over the past 6 years $(18,19)$; countries had failed to adopt stronger and more effective policies and reinforce the existing laws.

In the present study, we performed a quantitative analysis of the above-mentioned report (11) and tracked the status of tobacco control programmes in the $6 \mathrm{WHO}$ regions to create a challenge between countries to increase their performance. 


\section{Methods}

This cross-sectional study in summer 2018 collected information regarding the status of tobacco control programmes implemented in different countries worldwide using pages 136-149 of the 2017 MPOWER report (11). Two tobacco control experts designed a checklist and 5 experts in the field approved the scoring system of the checklist (12-14). The checklist and the scoring system used are presented in Table 1. For assessment of the 10 criteria ( 6 policies plus 1, 2 compliance and 1 prevalence) included in the report of each country, a 0-4 point scale was used for scoring the 5 -item criteria, and a $0-3$ point scale was used for scoring the 4 -item criteria. The maximum score was 37 . The scores were entered independently in the data collection sheet by 2 individuals and a third party compared the values and confirmed their accuracy. The scores were summed and presented in descending order.

Differences in mean scores were analysed by $t$ test and analysis of variance. $P<0.05$ was considered statistically significant.

\section{Results}

The highest mean score was recorded by the European Region (26.41), followed by: South-East Asia Region (25), Western Pacific Region (24.88), Region of the Americas (22.05), Eastern Mediterranean Region (21.40) and African Region (17.40) (Table 2). There were significant differences $(P<0.05)$ between the means.

The top 23 countries for tobacco control, which had at least $85 \%$ of the total score (i.e., 32 out of 37 ) are shown in Table 3. African Region: Seychelles and Mauritius 33, 2 of 47 countries, $4.2 \%$ of region. Region of the Americas: Costa Rica 36, Brazil and Panama 35, Surinam and Colombia 34, Canada, Uruguay and Argentina 33, 8 of 35 countries, $22.8 \%$ of region. European Region: United Kingdom of Great Britain and Northern Ireland (UK) and Turkey 36, Portugal, Russia and Ireland 33, Romania, Estonia, Denmark, Spain and Norway 32, 10 of 53 countries, $18.8 \%$ of region. Eastern Mediterranean Region: Islamic Republic of Iran 34, 1 of 22 countries, 4.5\% of region. South-East Asia Region: none. Western Pacific Region: Australia 35, New Zealand 34, 2 of 27 countries, $7.4 \%$ of region. Most of these countries (43\%) were from the European Region.

The scores for the Eastern Mediterranean Region countries are presented in Table 4. Between 2015 and 2017, the total score increased by 43 points. The trends in MPOWER scores from 2011 to 2019 in Eastern Mediterranean Region countries are shown in Table 5. Tables for the other regions are in the Supplementary File.

\section{Discussion}

The Eastern Mediterranean Region has not done well in implementing tobacco control programmes compared to other regions, and was only better than the African Region. This issue should be addressed by health policy-makers in the countries of the Eastern Mediter- ranean Region and they should adopt more thorough and far-reaching plans. There was a direct association between higher scores and a reduction in tobacco use, which reflects the fact that implementation of tobacco control programmes in the community, has an impact on the general public and results in a reduction in tobacco use. Taxation, because of its low ranking, should be given more attention in the Eastern Mediterranean Region. Between 2011 and 2019, implementation of the MPOWER package in the Region was considered important by governments and some achievements were made (score increased from 416 to 509) but many challenges remain for tobacco control programmes to reach the maximum score of 814 (37'22).

The Islamic Republic of Iran and Egypt maintained their status, and Saudi Arabia, Pakistan, United Arab Emirates (UAE) and Qatar improved theirs. Many others tried to maintain their status and Somalia had no improvement. More tobacco control programmes have been recently introduced in the Region but they need more time to realize their effectiveness. There was insufficient increase in smoke-free policy compliance and insufficient decrease in smoking prevalence; therefore, it seems that tobacco control has not been effective in decreasing tobacco consumption in the Region and protecting people from second-hand smoke.

All countries need to increase taxation rates to improve the overall effectiveness of tobacco control measures. For example, Egypt had a high overall score in 2017 but did not score well in smoke-free policies; consequently, more effective reinforcement measures need to be taken. The 2017 data show some challenges in implementing MPOWER policies in certain countries; for example, in Kuwait and Saudi Arabia there was a decrease in compliance with smoke-free policies. At the same time, other policies remained unchanged in the countries, such as the inclusion of graphic health warnings on cigarette packets. There has also been little steady progress in implementation of other policies, for example, raising taxation (20).

None of the countries scored full points in the tobacco control programmes; however, 23 countries (Seychelles, Mauritius, Costa Rica, Brazil, Panama, Surinam, Colombia, Canada, Uruguay, Argentina, UK, Turkey, Portugal, Russia, Ireland, Romania, Estonia, Denmark, Spain, Norway, Islamic Republic of Iran, Australia and New Zealand) had a superior status according to the 2017 MPOWER report. These 23 countries may act as a best model for others to implement and enforce tobacco control programmes. Comparison of scores of different countries can be beneficial since it creates a challenge for the health policy-makers to find weaknesses in their tobacco control programmes and improve them. In 2015, 15 countries acquired the highest scores included Panama and Turkey with 35 points, Brazil and Uruguay with 34, Ireland, UK, Iran, Brunei, Argentina and Costa Rica with 33, and Australia, Nepal, Thailand, Canada and Mauritius with 32 (14). Comparison between that study and the present study shows that 4 countries (Brunei, 


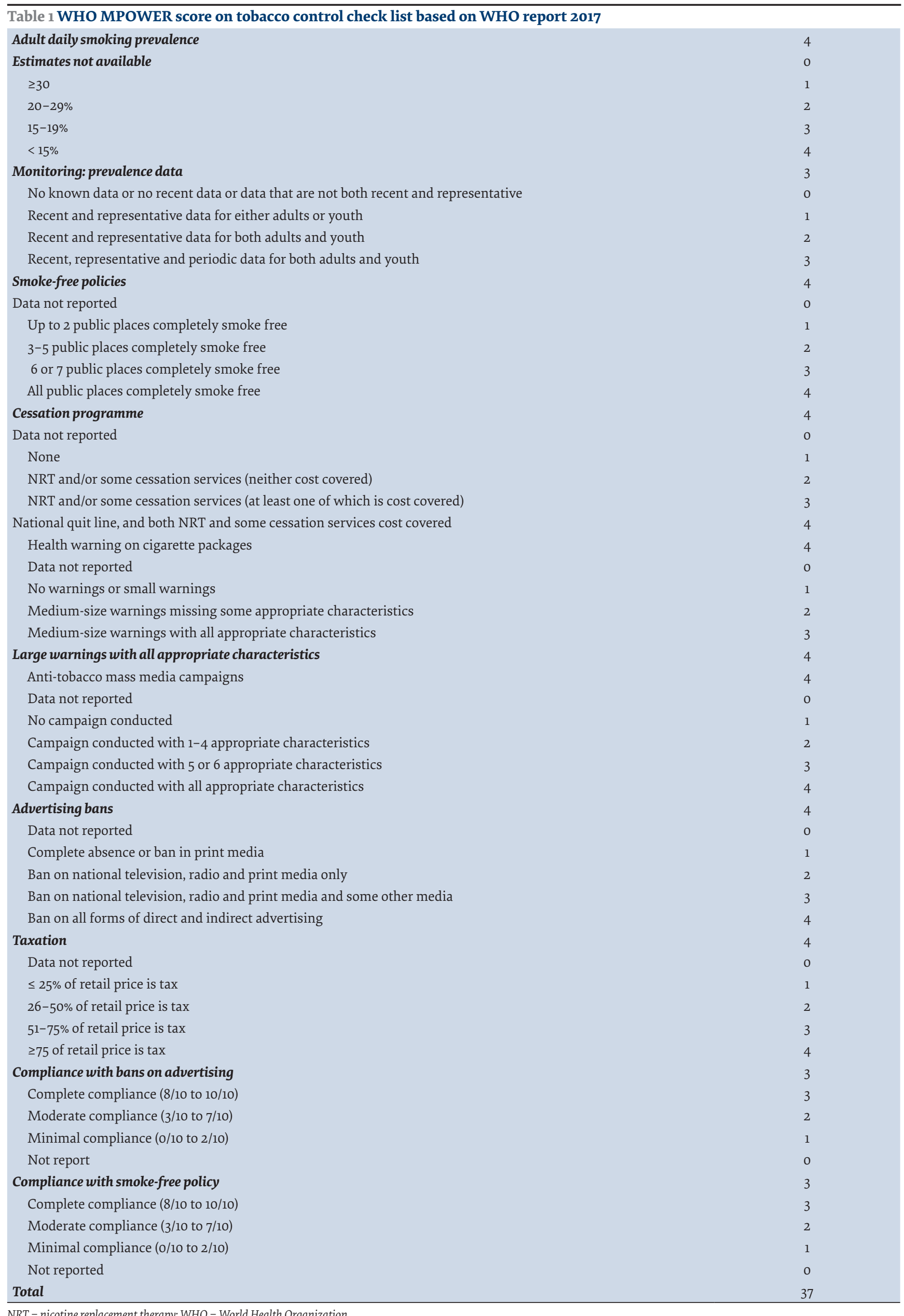




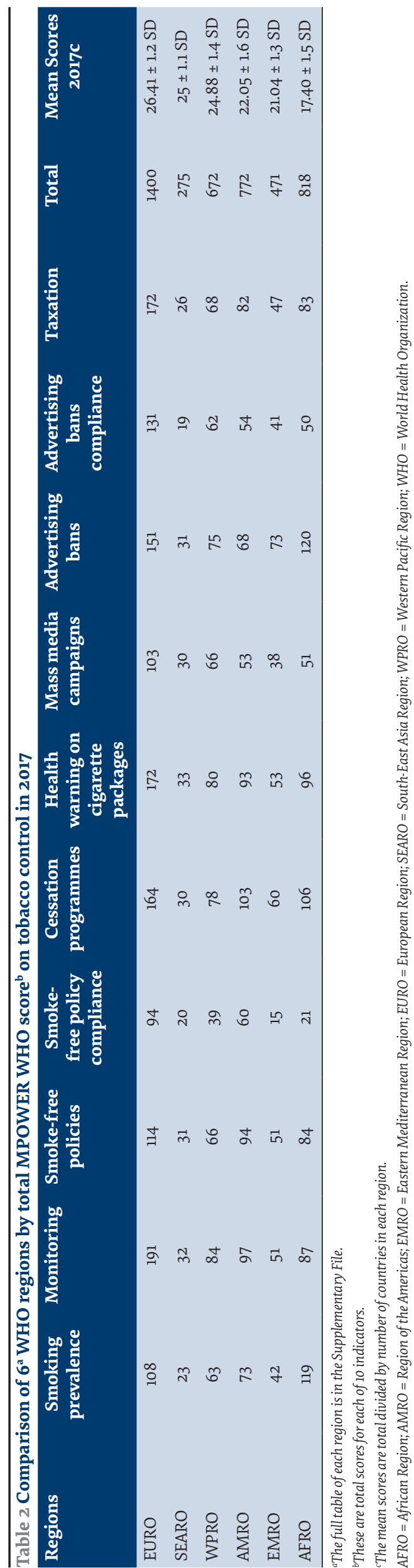

Nepal, Thailand and Mauritius) left and 12 new countries were added to this group. This may challenge countries to have more focus on tobacco control.

Since the scores were close and most countries had a 1-point difference, more precise implementation of each strategy and publishing a more thorough report may change the scores and consequently the ranking of countries in this respect. In 2017, all the regions had higher total scores compared with 2015: African Region +52 , Region of the Americas +59, South-East Asia Region +35 , European Region +109 , Eastern Mediterranean Region +43 and Western Pacific Region +43 . The highest mean score of 3.18 was for the South-East Asia Region followed by 2.05 for the European Region. It is notable that the South-East Asia Region had no country in the top 23 but it had the best improvement regionally. The largest improvement was in Timor Leste +13 , Cambodia +12 , El Salvador and Romania +9 , and Uganda, Rwanda and Syrian Arab Republic +8 , and largest reduction was in Cameron -7, Luxemburg -6, San Marino, Libya and Swaziland -5 .

To catch up with the progress of other WHO regions, in the Eastern Mediterranean Region, stronger measures need to be implemented and reinforced as part of comprehensive national plans that take into consideration all social and economic variables. A better outcome can be achieved by greater coordination and cooperation between the countries of the Region to draw up common control strategies. This has already been done successfully in other WHO regions in their fight against the global tobacco epidemic, as for example, in the European Region (21). The leading position of European countries in this regard was also found in a study by Joossens and Raw (22). No such study has been done in any other region of the world except in the Eastern Mediterranean Region (18); thus, this may be an important research topic for further studies and the results can be used to create a challenge and competition between countries in an effort to achieve better ranking.

Thepresentstudy had somelimitations. TheMPOWER reports do not refer specifically to waterpipe and other forms of tobacco smoking. Political, social and economic variables that support or act as barriers to tobacco control were not investigated in this study. These factors should be investigated in future studies. The interference of the tobacco industry with the implementation of the control programmes is not well reflected in such surveys. It is well known that the tobacco industry typically uses its large profits to expand its production, distribution and sale of its products as well to influence policy-makers in order to impede tobacco control programmes.

\section{Conclusion}

Although many efforts have been made in the Eastern Mediterranean Region, compared with other regions, many challenges to policy implementation and enforcement remain and require urgent action by governments. Comparison of scores of different countries in this respect can be beneficial since it creates a challenge for 


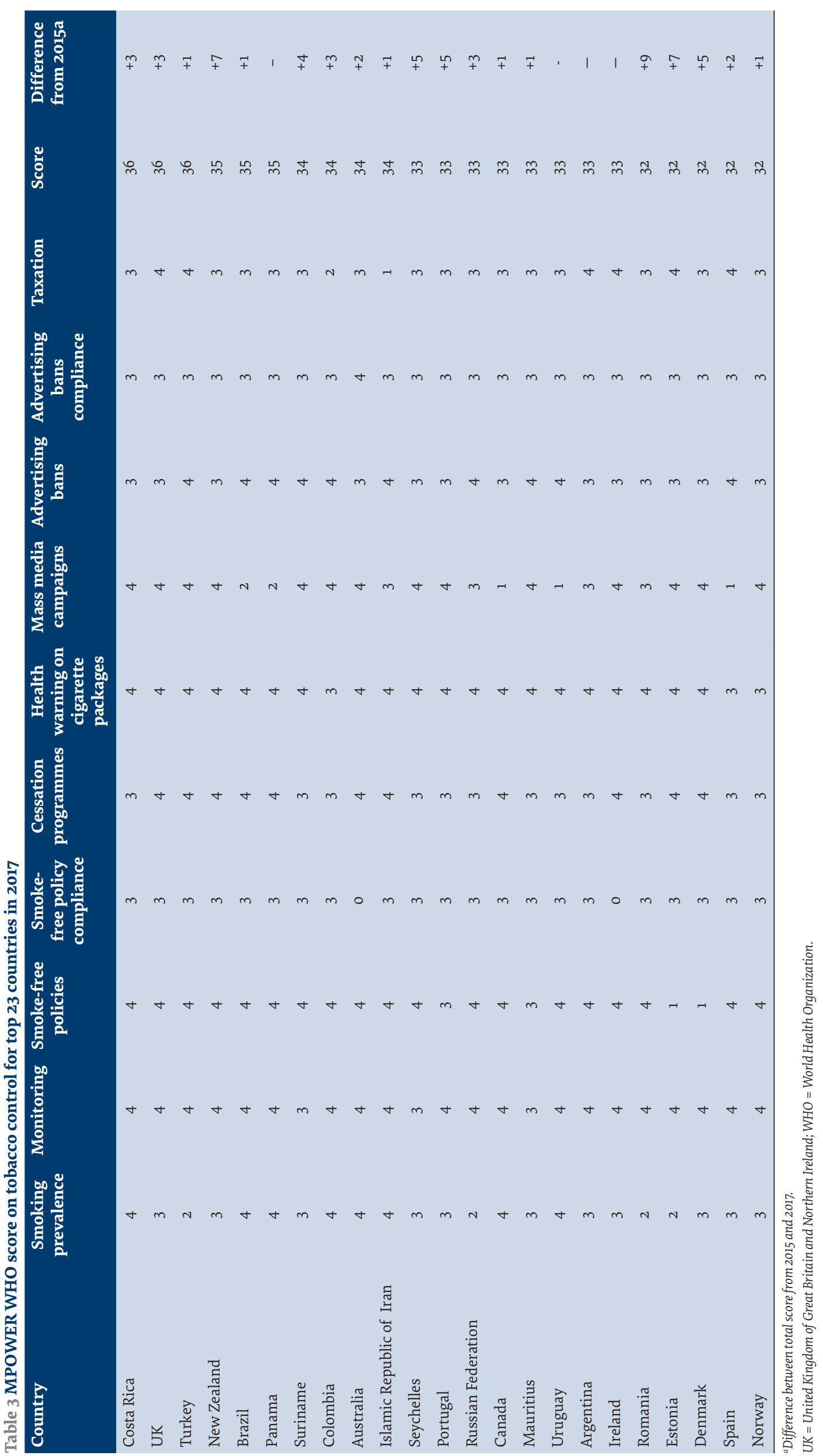




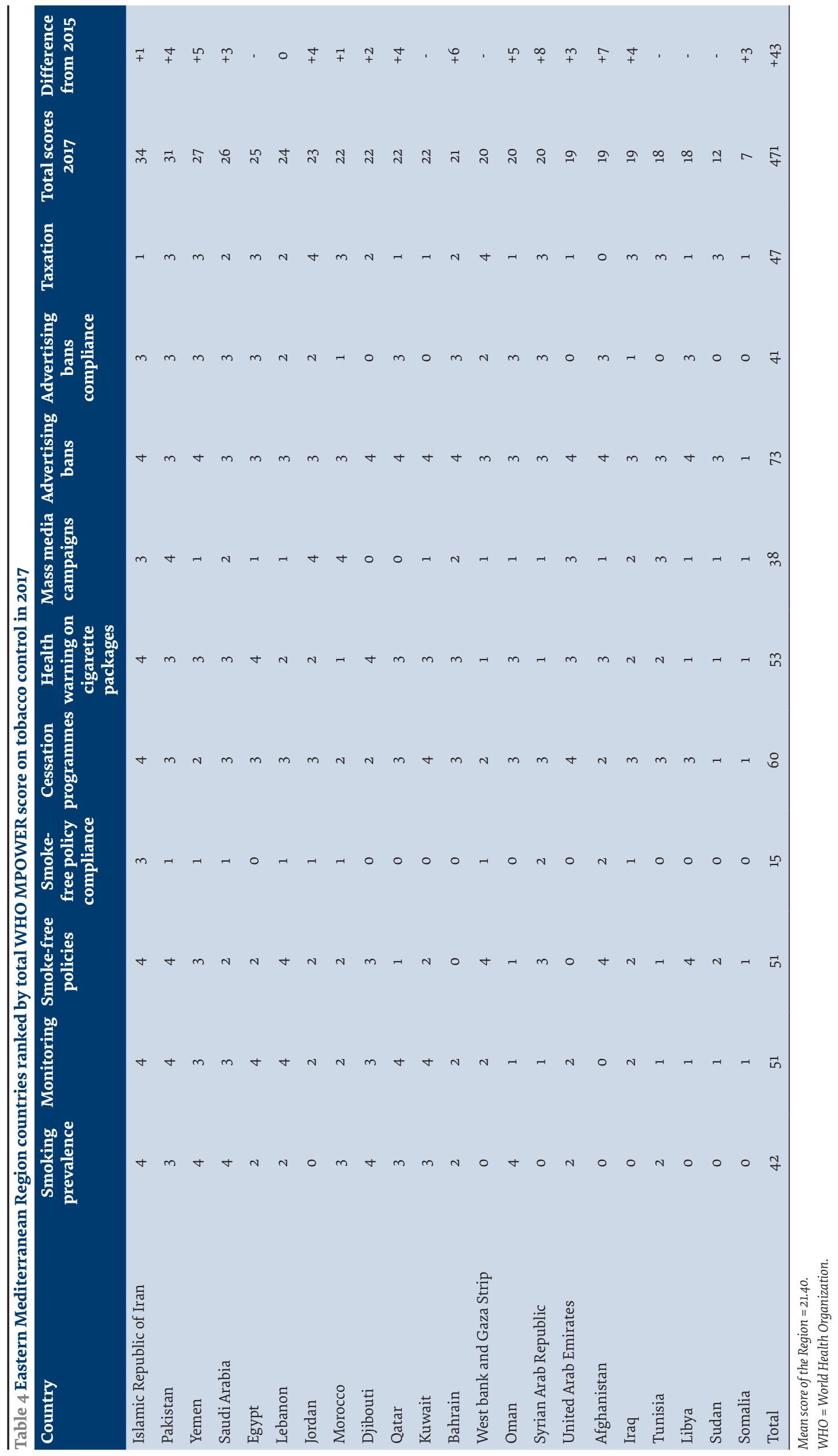




\begin{tabular}{|c|c|c|c|c|c|}
\hline Country & $\begin{array}{c}\text { Total scores } \\
2019\end{array}$ & $\begin{array}{c}\text { Total scores } \\
2017\end{array}$ & $\begin{array}{c}\text { Total scores } \\
2015\end{array}$ & $\begin{array}{c}\text { Total scores } \\
2013\end{array}$ & $\begin{array}{l}\text { Total scores } \\
\quad 2011\end{array}$ \\
\hline Islamic Republic of Iran & 32 & 34 & 33 & 31 & 29 \\
\hline Pakistan & 32 & 31 & 27 & 21 & 20 \\
\hline Saudi Arabia & 32 & 26 & 23 & 23 & 19 \\
\hline Egypt & 29 & 25 & 29 & 28 & 28 \\
\hline Qatar & 28 & 22 & 21 & 21 & 18 \\
\hline United Arab Emirates & 28 & 19 & 16 & 17 & 24 \\
\hline Yemen & 27 & 27 & 22 & 17 & 17 \\
\hline Lebanon & 25 & 24 & 24 & 26 & 17 \\
\hline Morocco & 24 & 22 & 22 & 17 & 17 \\
\hline Bahrain & 24 & 19 & 15 & 22 & 21 \\
\hline Iraq & 24 & 18 & 15 & 18 & 15 \\
\hline Jordan & 23 & 23 & 23 & 22 & 21 \\
\hline Kuwait & 22 & 22 & 23 & 28 & 21 \\
\hline West Bank and Gaza Strip & 22 & 20 & 21 & 25 & 20 \\
\hline Oman & 22 & 20 & 15 & 21 & 14 \\
\hline Tunisia & 22 & 18 & 20 & 21 & 17 \\
\hline Libya & 19 & 18 & 23 & 22 & 21 \\
\hline Syrian Arab Republic & 18 & 20 & 12 & 17 & 18 \\
\hline Afghanistan & 17 & 19 & 12 & 13 & 9 \\
\hline Sudan & 17 & 12 & 16 & 13 & 19 \\
\hline Djibouti & 15 & 22 & 21 & 25 & 20 \\
\hline Somalia & 7 & 7 & 4 & 6 & 7 \\
\hline Total (Region) & 509 & 471 & 428 & 453 & 416 \\
\hline
\end{tabular}

WHO = World Health Organization.

the countries to achieve a higher rank. The Region has to work more on full implementation of FCTC to reach a score of 814. Smoke-free policy compliance is the most challenging indicator for the Region. Somalia and Sudan must consider tobacco control as a top priority in their health programme. Some countries such as the Islamic Republic of Iran, Kuwait, Iraq and Libya must work more on tobacco taxation. For some countries such as Egypt, UAE, Oman, Kuwait, Libya, Afghanistan and Djibouti, mass media campaigns are important. Health warnings on cigarette packages must change in Morocco, Gaza and Syrian Arab Republic.

\section{Funding: None}

Competing interests: None

\section{Comparaison quantitative des mesures de lutte antitabac de l'OMS : enseignements tirés pour la Région de la Méditerranée orientale}

\section{Résumé}

Contexte: En 2018, l'Organisation mondiale de la Santé (OMS) a présenté un ensemble de mesures comprenant six politiques principales (MPOWER) en matière de lutte antitabac.

Objectifs : la présente étude avait pour objectif de réaliser une analyse quantitative du programme MPOWER dans les Régions de l'OMS.

Méthodes : La présente étude transversale a permis de recueillir des informations au cours de l'été 2018 en utilisant les pages 136 à 149 du rapport MPOWER 2017 et une liste de contrôle validée de 10 critères. Le score maximum possible était de 37. Ces scores ont été additionnés et présentés par ordre décroissant pour les six Régions de l'OMS.

Résultats : Le score moyen le plus élevé a été obtenu par la Région de l'Europe $(26,41)$, suivie par la Région de l'Asie du Sud-Est (25), la Région du Pacifique occidental $(24,88)$, la Région des Amériques $(22,05)$, la Région de la Méditerranée orientale $(21,40)$ et la Région de l'Afrique $(17,40)$. On a observé une différence significative $(p<0,05)$ en termes de moyennes. 
Conclusions : Bien que des progrès notables aient été réalisés dans la Région de la Méditerranée orientale, de nombreux défis entravant la mise en œuvre et l'application des politiques, par rapport aux autres régions, persistent et requièrent une intervention de toute urgence de la part des gouvernements de la Région.

$$
\text { غلارنة كمية لإجر اءات مكافحة التبغ في منظمة الصحة العالمية: دروس مستفادة من إقليم شرق المتوسط }
$$

الخلفية: طرحت منظمة الصحة العالمية في سنة م · · ب جمموعة من تدابير مكافحة تعاطي التبخ تضمنت ست سياسات رئيسية ججموعة (MPOWER) لمواجهة تعاطي التبخ.

$$
\text { الأهداف: هدفت هذه الدراسة إلى إجراء تحليل كمي لمجموعة السياسات الست في البلدان وفي أقاليم منظمة الصحة العالمية. }
$$

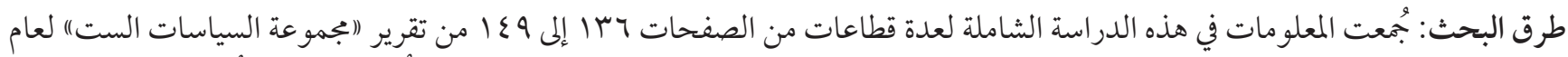

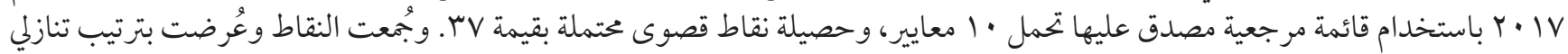
حسب أقاليم منظمة الصحة العالمية الستة.

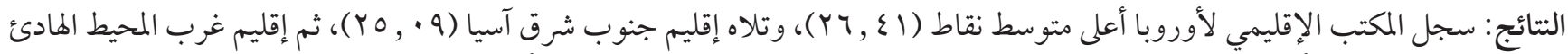

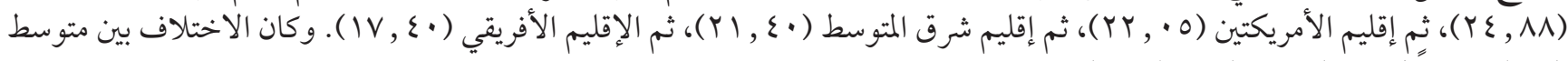

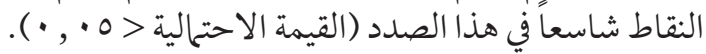

الاستنتاج: على الرغم من الإنجازات المهمة التي تحقّقت في إقليم شرق المتوسط، لا يزال هناك الكثير من التحديات أمام تنفيذ السياسات، وهو ما

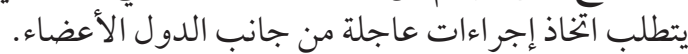

\section{References}

1. Ng M, Freeman MK, Fleming TD, Robinson M, Dwyer-Lindgren L, Thomson B et al. Smoking prevalence and cigarette consumption in 187 countries, 1980-2012, JAMA. 2014 Jan 8;311(2):183-92. http://dx.doi.org/10.1001/jama.2013.284692 PMID:24399557

2. Mathers CD, Loncar D. Projections of global mortality and burden of disease from 2002 to 2030. PLoS Med. 2006 Nov;3:e442. http://dx.doi.org/10.1371/journal.pmed.0030442 PMID17132052

3. Peto R, Boreham J, Thun M, Heath C Jr, Doll R. Mortality from smoking worldwide. Br Med Bull. 1996 Jan;52:12-21. http://dx.doi. org/10.1093/oxfordjournals.bmb.a011519 PMID:8746293

4. Levine R, Kinder M. Millions saved: proven successes in global health. Washington DC: Center for Global Development; 2004

5. Big Tobacco finally forced to tell the truth about its deadly products through court-ordered ads [website] (https://truthinitiative. org/press/press-release/big-tobacco-finally-forced-tell-truth-about-its-deadly-products-through-court, accessed 17 December 2019).

6. WHO Framework Convention on Tobacco Control. Geneva: World Health Organization: 2003 (http://www.who.int/fctc/text download/en/, accessed 17 December 2019).

7. Tobacco Free Initiative (TFI) [website]. Geneva: World Health Organization; 2019 (http://www.who.int/entity/tobacco/mpower/ en/, accessed 17 December 2019).

8. Guindon GE, Boisclair D. Past, current and future trends in tobacco use. Washington DC: World Bank, 2003 (http://documents. worldbank.org/curated/en/374771468128405516/pdf/292650GuindonıPast1ocurrent1owhole.pdf, accessed 17 December 2019).

9. Basu S. Glantz S, Bitoon A, Millet C. The effect of tobacco control measures during a period of rising cardiovascular Disease Risk in India: a mathematical model of myocardial information and stroke. PloS Med. 2013;10(7):e1001480. http://dx.doi.org/10.371/ journal.pmed.1001480 PMID:23874160

10. Levy D, Ellis JA, Mays D, Huang AT. Smoking related deaths averted due to three years of policy progress. Bull World Health Organ. 2013 Jul 1;91(7):509-18. http://dx.doi.org/10.2471/BLT.12.113878 PMID:23825878

11. WHO report on the global tobacco epidemic 2017. Monitoring tobacco use and prevention policies. Geneva: World Health Organization; 2017 (http://www.who.int/tobacco/global_report/2017/en/, accessed 17 December 2019).

12. Heydari G, Talischi F, Algouhmani H, Lando HA, Ahmady AE. WHO MPOWER tobacco control scores in the Eastern Mediterranean countries based on the 2011 report. East Mediterr Health J. 2013;12(4):314-9. https://apps.who.int/iris/bitstream/handle/10665/118388/EMHJ_2013_19_4_314_319.pdf?sequence=1\&isAllowed=y

13. Heydari G, Ebn Ahmady A, Lando HA, Shadmehr MB, Fadaizadeh L. et al. The second study on WHO MPOWER tobacco control scores in the Eastern Mediterranean Countries based on the 2013 report: improvements during two years. Arch Iran Med. 2014 Sep;17(9):621-5. http://dx.doi.org/0141709/AIM.007 PMID:25204478 
14. Heydari G, Chamyani F, Masjedi M, Fadaizadeh L. Comparison of tobacco control programs worldwide: a quantitative analysis of the 2015 World Health Organization POWER Report. Int J Prev Med. 2016 Dec 12;7:127. http://dx.doi.org/10.4103/20087802.195562 PMID:28105292

15. Wipfli H. The FCTC turns 10: lessons from the fist decade. J Epidemiol. 2016 Jun 5;26(6):279-83. http://dx.doi.org/10.2188/jea. JE20160080 PMID:27180935

16. Gravely S, Giovino GA, Craig L, Commar A, D'Espaignet ET, Schotte K, et al. Implementation of key demand-reduction measures of the WHO Framework Convention on Tobacco Control and change in smoking prevalence in 126 countries: an association study. Lancet Public Health. 2017 Apr;2(4):e166-74. http://dx.doi.org/10.1016/S2468-2667(17)30045-2 PMID:29253448

17. Cairney P, Mamudu H. The global tobacco control 'endgame': change the policy environment to implement the FCTC. J Public Health Policy. 2014 Nov;35(4):506-17. http://dx.doi.org/10.1057/jphp.2014.18 PMID:24831675

18. Heydari G, Talischi F, Masjedi MR, Alguomani H, Joossens L, Ghafari M. Comparison of tobacco control policies in the Eastern Mediterranean countries based on tobacco control scale scores. East Mediterr Health J. 2012 Aug;18(8):803-10. http://dx.doi. org/10.26719/2012.18.8.803 PMID:23057368

19. Heydari G, EbnAhmady A, Lando H, Chamyani F, Masjedi MR, Shadmehr M, et al. The third study on WHO MPOWER tobacco control scores in Eastern Mediterranean Countries based on the 2015 report. East Mediterr Health J. 2017 Nov 19;23(9):598-603. PMID:29178116

20. WHO report on the global tobacco epidemic 2019. Geneva: World Health Organization; 2019 (https://www.who.int/tobacco/global_report/en/, accessed 17 December 2019).

21. Heydair G, Zaatari G, Al-Lawati J, El-Awa F, Fouad H. MPOWER, needs and challenges: trends in the implementation of the WHO FCTC in the Eastern Mediterranean Region. East Mediterr Health J. 2018;24(1):63-71. https://doi.org/10.26719/2018.24.1.63

22. Joossens L, Raw M. The tobacco control scale: a new scale to measure country activity. Tobacco Control. 2006 Jun;15(3):247-53. http://dx.doi.org/10.1136/tc.2005.015347 PMID:16728757 